\title{
Elucidating the blurred lines of the national historical imagination. The narrative allure of Sienkiewicz's With Fire and Sword in 1933-1934 Poland
}

\author{
Estelle BUNOUT \\ Postdoctoral researcher \\ Centre for Contemporary and Digital History $\left(\mathrm{C}^{2} \mathrm{DH}\right)$, \\ Université du Luxembourg (LU)
}

Estelle.Bunout@uni.lu

\begin{abstract}
The novel With Fire and Sword by Henry Sienkiewicz (1846-1916) is an example of the interweaving of fiction, historiography and national collective imagination. It was written at the end of the period of Polish partition (1882-1888) and deals with events that marked the history and the collective imaginations of Poles, Ukrainians and Jews: the history of the Khmel'nyts'kyy Uprising (1648-1657). The epic nature of these historical events already carried the seeds of a powerful and emotional narrative that lends itself to mythicization. However, the reading of this book in a later situation, the Second Polish Republic (1921-1939), led the Polish Sanacja government to withdraw it from the compulsory reading in Polish schools in 1932.

This aspect of the Jędrzejewicz school reform sparked a lively debate in the Polish press, whereby historians, literature scholars and journalists discussed the function that this book should have in the patriotic education of young Polish citizens, against the backdrop of tensions between the state and the political opposition on the issue of minorities, namely the Ukrainian minority. This discussion discloses the central place that Sienkiewicz has been given in Polish culture. At the same time, it examines the position that Polish intellectuals attribute to the Ukrainian minority in the Polish state and culture.
\end{abstract}

Keywords: Sienkiewicz, Second Polish Republic, Ukrainian minority, school reform.

\section{Résumé :}

Le roman Par le fer et par le feu de Henry Sienkiewicz (1846-1916) est un exemple d'entrelacement de fiction, d'historiographie et d’imaginaires collectifs nationaux. Il a été écrit à la fin de la période de partition polonaise (1882-1888) et traite d'événements qui ont marqué l'histoire et les imaginaires collectifs polonais, ukrainiens et juifs : l'histoire du soulèvement de Khmelnytsky (1648-1657). La nature épique de ces événements historiques portait déjà les germes d'un récit puissant et émotionnel qui se prête à la mythification. Cependant, la lecture de ce livre dans une situation ultérieure, la Deuxième République polonaise (1921-1939), a conduit le gouvernement polonais de Sanacja à retirer ce livre de la lecture obligatoire dans les écoles polonaises en 1932.

Cet aspect de la réforme scolaire de Jędrzejewicz a suscité une discussion nourrie dans la presse polonaise, où les historiens, les spécialistes de la littérature et les journalistes ont discuté de la fonction que ce roman et la narration qu'il portait devait avoir dans l'éducation patriotique des jeunes citoyens polonais, sur fond de tensions entre l'État et l'opposition politique sur la question des minorités, en particulier la minorité ukrainienne. Cette discussion resitue la place centrale qui a été attribuée dans la culture polonaise à Sienkiewicz. Dans le même temps, elle interroge la position que les intellectuels polonais attribuent à la minorité ukrainienne dans l’État et la culture polonais.

Mots-clés : Sienkiewicz, $2^{e}$ République polonaise, minorité ukrainienne, réforme scolaire. 


\section{Elucidating the blurred lines of the national historical imagination. The narrative allure of Sienkiewicz's With Fire and Sword in 1933-1934 Poland}

What happens to a novel that depicts a vision of a society's past that is strongly anchored in a particular historical situation, when the context changes? With Fire and Sword [Ogniem i mieczem] was written by Henry Sienkiewicz (1846-1916) towards the end of the period of Polish partition (1882-1888), about the history of the Khmel'nyts'kyy Uprising (1648-1657), which led to the creation of a Cossack Hetmanate in Ukrainian lands. The Cossacks, allied with the Tatars, fought against the Polish-Lithuanian Commonwealth, before coming to an agreement with Muscovy in 1654.

What made the story so fascinating? Against the historical backdrop of the Khmel'nyts'kyy Uprising, Sienkiewicz portrays a love triangle between a fictional princess and two semi-fictional Polish and Ukrainian characters (Jan Skrzetuski and Jurko Bohun). Most of the narrative focuses on the depiction of the Uprising, the description of the battles and the cruelty of the protagonists involved, especially among the Polish aristocrats, in particular Jeremi (Yarema) Wiśniowiecki (Kosman 1999). This intertwining of fiction and historical reality was discussed as soon as the novel was published. Since it was written at a particular political time for the Poles, when the country was partitioned and there was no Polish state, it bears traces of the preoccupations of that time and the role attributed to literature in that context. The novel has been repeatedly discussed, with each new context adding a new layer of intertwined historical knowledge and shifting the definition of Polish national culture and its relations with other peoples in the region, foremost the Ukrainians. With this first novel, Sienkiewicz rapidly became one of the most popular writers of his time, widely respected for his historical erudition. His novel resonated widely in Polish society across the partitions and had a lasting impact on the national historical imagination, even after the Polish state was created following World War I. However, by the 1930s, the historical imagination it conveyed did not suit the agenda of the government, which decided to remove it from the compulsory school reading list in 1933. This decision was followed by a fierce discussion of the novel and the legitimacy of its position at the centre of the national imagination.

We propose to focus here on this discussion in the Polish press that took place in 1933-1934 during the Second Polish Republic, in the context of tensions between

CONNEXE 5 | 2019 - Divided Memories, Shared Memories, Poland, Russia, Ukraine: History mirrored in Literature and Cinema 
the state and the political opposition over the question of minorities, especially the Ukrainian minority. In order to understand the implications of the debate, which involved historians, journalists and activists for Polish-Ukrainian dialogue, we first need to try and untwine the elements of the discussion around Sienkiewicz's novel: the historical backdrop against which it was written, the context of the events it depicts and finally the historiographical debate that followed it.

\section{Untwining the chronologies: With Fire and Sword as a product of the late 19th century}

Sienkiewicz succeeded in capturing and simultaneously shaping the Polish collective representation of a crucial period in the region's history. His novel, intertwining the historical topic and historiographical knowledge with the author's talent, created a lasting image of 17 th century Polish culture at the turn of the 19-20th centuries. In the following section we recontextualise the creation of the novel in its cultural and historiographical context.

\subsection{Writing With Fire and Sword at the end of the period of Polish partition (1882-1888)}

Sienkiewicz was a journalist and author who became famous for his serialised novels in the 1880s. These were enormously popular in Poland and beyond. In 1905 he received the Nobel Prize in Literature for his novel Quo Vadis. His works were published, as was customary, in newspapers, in serialised form (as a series of "felietons" - the word is derived from the French feuilleton), initially in the conservative dailies Stowo in Warsaw and Czas in Kraków, between 1882 and 1884 (Bujnicki 2016, 127). In other words, his serialised novel was read across partitioned Poland. This first series launched his trilogy, ${ }^{1}$ published until 1888, and marked his transition from journalism to literature. The feuilleton was a product of the "civilisation of the newspaper," ${ }^{2}$ where the spheres of literature and journalism overlapped significantly in terms of both writers and writing practices. Literary and press texts became increasingly related, with news stories becoming a source of inspiration for the authors, as for instance with The Count of Monte Cristo by Alexandre Dumas (1844-1846) (Dumasy-Queffélec 2011, 930). The format may have had some influence on the sensationalism of the text, including the frequent brutal scenes that later became the focus of criticism.

1 Sienkiewicz dedicated three books to depicting a Polish historical fresco: Ogniem i mieczem [With fire and sword] (1884), Potop [The Deluge] (1886), Pan Wolodyjowski [Fire in the Steppe] (1888).

2 As coined by the authors of the eponymous book: Kalifa et al. 2011. 
Sienkiewicz wrote during the heyday of naturalism but distanced himself from the "scientism" of that literary field, which implied that the distant past could not be the object of realist literature since it was inaccessible by direct observation. On the contrary, Sienkiewicz seems to have considered literature an effective way of understanding his past compatriots and bringing them closer to his contemporaries. This was part of a broader phenomenon, described by Anne-Marie Thiesse as the writing of the "national novel" in the 19th century, when in several European countries, novelists took upon themselves to narrate -in order to define- a national history (Thiesse 2001, 133). Sienkiewicz took inspiration from historical events, in particular via the works of the historian Ludwik Kubala (1838-1918). Immediately before starting to write the first part of the trilogy that would define him as a historical novelist, Sienkiewicz began by writing a few reviews of historians' works. As pieced together by the Sienkiewicz specialist Tadeusz Bujnicki, at that point Sienkiewicz was already beginning his reflections on the role of literature as shedding light on the past in general, and on a nation's past in particular (Bujnicki 2016). The persistent problem Sienkiewicz faced was how to build a narrative on the national past that would convey a patriotic feeling in the current context of a defeated Polish political elite, after the failed insurrection of 1863 (the January Uprising). He was writing in the context of the late partition period, during which there was no Polish state and consequently no Polish schools and no Polish history classes. ${ }^{3}$ Literature was hence an effective alternative for educating young people and society in general about its past. Creating a narrative out of the past is a means of structuring facts and creating the illusion of an ordered, logical series of events. As Bujnicki points out, Sienkiewicz preferred to depict history in a way that was credible rather than realistic (Bujnicki 2016, 131). Moreover, a novel enables the past to be recreated via characters, their language and the depiction of their mentality and values, thereby bridging any gaps in information available in archives on the particular state of mind of a historical figure, especially from the distant past (or of figures that left no trace in the archives) (Bujnicki 2016, 133). Sienkiewicz's work should be read in the context of his stay in the United States before writing of With Fire and Sword ${ }^{4}$ and also as a response to the negative imagery of the Polish aristocrat as depicted a few decades earlier by Nikolay Gogol (1809-1852) in

3 In the Russian Empire, there was no compulsory schooling in contrast to the Prussian jurisdiction, where school was used as a mean to germanise Polish pupils. The Austrian Empire allowed Polish classes (Radzikowska 2015, 29).

4 Bujnicki indicates that Sienkiewicz, when confronted with the myth of the frontier in the US, reacted by contrasting it to the Ukrainian borderlands: the US frontier seems to have "bored" him, as it was "empty" in comparison to Ukraine, where the air was full of the cries and shouts of the locals (Bujnicki 2007a, 253).

CONNEXE 5 | 2019 - Divided Memories, Shared Memories, Poland, Russia, Ukraine: History mirrored in Literature and Cinema 
Taras Bulba (Gautier 2009; Bujnicki 2007b). It is often described as a "balm" for Polish patriotism in the context of the late partition period (Chemodanova 2014, 252). Alongside the author's writing talent, this triple lineage -drawing on the imagery of the Cossacks and Ukraine, the sensationalist feuilleton writing style and the contemporary historiographical state of the art - enlightens the lasting debates that surround this particular publication. The hybrid nature of the novel, offering several layers of reading, accounts for its controversial reception - which was regularly updated- beyond the sphere of literary criticism. The novel was therefore born of creative work based on actual knowledge, not only from archives but also the use of historical language, to recreate mentalities. With Fire and Sword blends the Polish romantic literary thematic tradition and is written in the context of positivism, which is reflected in this documentary foundation (Bujnicki 2007a, 252-253). It is a product of its time, echoing the use of literature as a way to create a common narrative for the Polish nation, anchored in a mythified territory (Bujnicki 2007a, 263). The ultimate goal was to inscribe Polish history in the region by describing the conflict as a "fratricidal" war, emphasising the common destiny of Poles and Ukrainians so as to relativise the history of the Polish partition.

As Bujnicki summarises it:

The author stood before a fundamental dilemma: either striving to represent the wheelwork and mainspring of the historical "watch" [in reference to B. Prus' review on With Fire and Sword], or rather creating a drama, with emotions of military struggles plotted over it, in which the political motives of the parties involved are destroyed by self-driven brutality and destructive instincts" (Bujnicki 2007a, 267).

In other words, Sienkiewicz relied on elements of social imagination that he crystallised and reframed in a particular historical context, using the particular function that literature played in a divided Polish society, as a powerful ersatz for shared political and educational structures. As described by the French Revolution historian Bronisław Baczko, the social imagination locates "specific landmarks" in the "vast symbolic system" of a given society (Baczko 1984, 32). These landmarks are updated and their value changes over time. Sienkiewicz's novel effectively illustrates how particular elements of the collective memory, jointly produced by intellectuals and echoing current political preoccupations, can be recreated and reshaped over a long period by this same collective imagination. When the context changes, however, the social imagination of the historically determined vision of a particular event may be characterised by a strong inertia and its social aura prevents us from rethinking its social function, as was the case with Sienkiewicz's novel during the Second Polish Republic after 1921. In the following section, we 
will focus not on how the novel contributed to shape a certain Polish national narrative, but on the inertia of these collective representations and how they can collude with a new political situation. In order to emphasise the contrast between representation and historical backdrop, we will however review the historical events on which the novel is based and the historiographical debate in which it was created.

\subsection{The transnational historical and historiographical background to the novel: The Khmel'nyts'kyy Uprising (1648) from a regional perspective in the 19th century}

In 1888, not long after Sienkiewicz's novel was published, a monument to Bohdan Khmel'nyts'kyy (1595-1657) was erected in Kyiv, then part of the Russian Empire, as a symbol of the "delivery from the Polish yoke" (Sysyn 1998b, 531). Bohdan Khmel'nyts'kyy was celebrated in the Russian context because of his pledge of allegiance to the Tsar of Muscovy in Pereyaslav in January 1654, long interpreted as the first step towards a "union" between Ukraine and Russia. ${ }^{5}$ This part of the Uprising's history is left out of Sienkiewicz's novel, as is Muscovy in general. Instead, Sienkiewicz concentrates on the "fratricidal" war between Poles and Ukrainians. The underlying question plotted in the text and inspired by the Polish historiographical preoccupation developing over the centuries was what caused the Polish-Lithuanian Commonwealth, then presented as the first Polish state, to disappear (Sysyn 1998b; Glaser 2015). But the figure of Khmel'nyts'kyy has much broader implications. Khmel'nyts'kyy was a central figure in the historiographical debates in Poland and also in Ukraine (and Russia) over the question of statehood for Poland and Ukraine and also the issue of anti-Semitic violence in the region (Glaser 2015).

Indeed, the historical impact of Bohdan Khmel'nyts'kyy in the region had lasting consequences (Glaser and Sysyn 2015). He was born as a subject of the Polish-Lithuanian Commonwealth into the lesser Ukrainian nobility and baptised as Orthodox. He participated as a young man in the Battle of Cecora in 1620 that opposed the Poles and the Ottoman Empire. After this battle, he joined the registered Cossacks. Later, he participated in the battles against the Crimean Khanate in 1644. In other words, the path of his early life was typical of the lesser nobility, alternating between wars and land management. He acquired military experience in the Polish army and enjoyed the tenure of land granted by the local magnate, Stanisław Koniecpolski (1591-1646). It was in 1646 that

5 See the Monument to the Pereyaslav Council of 1654, built in 1954 in Kyiv, currently under another controversial monument of the People's Friendship Arch in Kyiv, built in 1982.

CONNEXE 5 | 2019 - Divided Memories, Shared Memories, Poland, Russia, Ukraine: History mirrored in Literature and Cinema 
his social situation changed when the land was redrawn following the death of Stanisław Koniecpolski, causing Khmel'nyts'kyy to lose control of his land to a Polish nobleman. This spurred a dispute between Bohdan Khmel'nyts'kyy and the Polish aristocracy and Crown that seems to have led Khmel'nyts'kyy to search for support among the Cossacks. ${ }^{6}$ The Cossacks were a diverse group: some were "registered" Cossacks, i.e. integrated into the armies of the Polish nobility. The first nobleman to lead these registered Cossacks was Michał Wiśniowiecki (15291584), a Ruthenian Hetman of the Zaporozhian Cossacks and grandfather of Jeremi Wiśniowiecki (1612-1651). Efforts to incorporate these groups of soldiers, who were more or less independent from the powerful regional aristocracy, were important for political stability in the region. Indeed, serfdom was in force, and the Cossacks offered an attractive alternative for many peasants. Khmel'nyts'kyy gathered supporters and started spreading the word for an uprising after failing to have his land privileges recognised. His calls met with significant support among the population of the region. However, before facing the Polish-Lithuanian Crown army, he also sought an alliance with the Tatars of Crimea. During the first months of the Uprising, the rebels won many battles and conquered significant portions of the territory of the southern-eastern part of the Polish-Lithuanian Commonwealth (Beauvois 2010, 142).

A few weeks after the start of the Uprising, the elected Polish king, Władysław IV Vasa (1595-1648), died without an heir. John II Casimir (1609-1672) was elected a few weeks later. Benefiting from the relative demobilisation of and many defections from the Polish forces, Khmel'nyts'kyy and his troops were able to enjoy significant victories in the first months of the Uprising. This resulted in some recognition of autonomy and privileges for the Orthodox Church and the Cossacks by the Treaty of Zboriv (17 August 1649). The situation did not last for long, however, and soon after the hostilities began anew. Khmel'nyts'kyy then sought support from Muscovy, which materialised in the Pereyaslav Agreement between Khmel'nyts'kyy's Cossacks and Muscovy (1654); this in turn led to the Polish-Russian war (1654-1667) and the subsequent Swedish invasion of Poland.

Bohdan Khmel'nyts'kyy and the uprising he led help shed light on the social and political conflicts that were poisoning relations between the inhabitants of the Commonwealth created after the Union of Lublin between Poland and Lithuania (1569) and transformed by the Union of Brest (1596). ${ }^{7}$

6 The depiction of this event as a reason for Khmel'nyts'kyy joining the rebellion varied according to the need to stress either his self-centred motives to lead the Uprising or the oppression of the Cossacks and the Ukrainian people by the rule of Polish magnates in the region (Koznarsky 2015, 101).

7 The union between the Catholic Church and the Orthodox churches of the Polish-Lithuanian Commonwealth.

CONNEXE 5 | 2019 - Divided Memories, Shared Memories, Poland, Russia, Ukraine: History mirrored in Literature and Cinema 
Correspondingly among Ukrainian historians, the Khmel'nyts'kyy Uprising has been interpreted in the light of the question of statehood.

From the first publications analysing Khmel'nyts'kyy and the Uprising, the line between the restitution of historical facts, stylisation of historical genres and shaping of myths is a blurred one. ${ }^{8}$ The first text published on the Uprising was written by Natan Hanover (unknown-1663) ("YIVO | Hannover, Natan Note" n.d.), a witness of the Cossack massacres against Jewish populations in the summer of 1648, who fled to Italy, where he published his text in Hebrew, Yeven metzulah, translated as Abyss of Despair (Hannover and Mesch 1983). As Adam Teller explains, this text combines historical accounts of the political context and the violence itself with biblical prophecies of such violent events against the Jews, portraying Khmel'nyts'kyy as both a historical figure and a divine instrument (Teller 2015, 111). Samuel Twardowski (before 1600-1661), a Polish chronicler, portrayed Khmel'nyts'kyy as the "villain" of a "civil war" in an eponymous poem published in 1681, whereas on the Ukrainian side, a few decades later, two texts by Samiilo Velychko (1670-1728) and Hryhorii Hrabianka (16861737/1738), stylised as chronicles, ${ }^{9}$ represented Khmel'nyts'kyy as a hero (Sysyn 2015, 40). The predominant narratives on the Uprising and Khmel'nyts'kyy's historical role contained elements of mythology and used the codes of historical sources or testimonies. Considering the violence of the Uprising and the major transformation it brought about, it is not surprising that accounts about this highly political combat would be divergent. This hybrid mix of mythology and seemingly factual rendering in these sources cast a lasting shadow on Jewish, Polish and Ukrainian historiographical discussions (Glaser 2015). The epic nature of these historical events already carried the seeds of a powerful and emotional narrative that almost naturally lent itself to mythicisation.

In Ukrainian historiography, the figure of Bohdan Khmel'nyts'kyy is discussed in the context of the continuity of a Ukrainian state and culture, in the dual historiographical filiation of Ukrainian statehood: Kievan Rus' and the Cossacks (Chemodanova 2014, 250). In Polish historiography from the same period, the Khmel'nyts'kyy Uprising is discussed in the context of the debate on the causes of the decline and later partition of the Polish-Lithuanian Commonwealth. In the 19th century, Ukrainian historiography moved from a "people-centred" to a "state-centred" approach, and this was reflected in the views on Khmel'nyts'kyy's

8 See the extensive volume edited by Amelia M. Glaser that reconstructs the diversity of the myths around Khmel'nyts'kyy and links them to various historical sources and their changing use over time (Glaser 2015).

9 According to Frank Sysyn, the stylisation consisted in the voluntarily archaic style in which the chronicles were written, to emphasise their value as historical primary sources - a common 18th-century practice.

CONNEXE 5 | 2019 - Divided Memories, Shared Memories, Poland, Russia, Ukraine: History mirrored in Literature and Cinema 
Uprising (Sysyn 1998a). In 19th-century Polish historiography, this Uprising was seen first as a popular uprising, overshadowing the national dimension (Joachim Lelewel, 1786-1861), then as a means of criticising Polish magnates (Karol Szajnocha, 1818-1868) (Sysyn 1998b). By the end of the 19th century, Ludwik Kubala reversed that interpretation and analysed this uprising as a challenge to Polish statehood before the partition of Poland in the 18th century. The publication of With Fire and Sword was therefore received in a tense, broader historiographical debate. Volodymyr Antonovych (1834-1908), a key figure in Ukrainian historiography on the Cossacks and the state-centred approach, wrote a sharp review of With Fire and Sword, criticising the "anti-Ukrainian" tone of the novel. ${ }^{10}$ For Antonovych, Sienkiewicz's novel both despises the Ukrainian peasantry and dismisses the legitimacy of the Cossacks' political fight for emancipation, two important themes of his own work to establish a Ukrainian historiography.

This brief historiographical review shows how Sienkiewicz's novel was one of many milestones in the construction of myths surrounding the event. We will now look at how the Polish state and society made use of the novel as a means of demonstrating the veneration that surrounded the novel itself and the subsequent social function it was given.

\section{3 "Our" Sienkiewicz: The aura of the trilogy in the Second Polish Republic (1921-1933)}

Sienkiewicz remained a prominent figure in Polish culture after 1918. He had died in Switzerland in 1916, during World War I, but his remains were repatriated to Poland after the refoundation of the Polish state, in 1924, and ceremonies were held to welcome them. In that year, the poet Jarosław Iwaszkiewicz (1894-1980) wrote a text bearing the telling title "Nasz Sienkiewicz" (Our Sienkiewicz), in which he explained that although Sienkiewicz was known worldwide for Quo Vadis, the novel that had the most impact for Poles was With Fire and Sword (Iwaszkiewicz 2016). Iwaszkiewicz describes Sienkiewicz as the "educator of generations of Poles," both in art and history. Sienkiewicz taught the Poles a "historical method applied to social issues" and inspired the rebuilding of a Polish state. Simply put, in Iwaszkiewicz's words, Sienkiewicz's trilogy became a "Polish historical gospel."

This ambiguous role of Sienkiewicz's work as a means of popularising historical knowledge while also raising patriotic awareness, inherited from the context of its creation as described above, was transposed in the context of the new Polish

10 Quoted from Chemodanova 2014, 254-255.

CONNEXE 5 | 2019 - Divided Memories, Shared Memories, Poland, Russia, Ukraine: History mirrored in Literature and Cinema 
state after 1921. One example of this twofold mission is the work of the literature historian and linguist Juliusz Kijas (1899-1967) on With Fire and Sword (Kijas 1927). In an article summarising his research, he analyses the sources Sienkiewicz used scene by scene, either agreeing, or more rarely disagreeing, with Sienkiewicz's loyal use of the Polish historiography of his time. Based on this "general loyal use" and the critical distance Sienkiewicz took towards the historiography and sources he consulted, Kijas concludes that Sienkiewicz's work reflects considerable historical research, expressed in an "artistic way" (Kijas 1927, 134-135).

This artistic recognition, together with the novel's patriotic content, led to it being used -together with the other two books in the Trilogy- as a prominent tool for educating pupils in the newly founded state. In 1924, it even became compulsory reading for the $7^{\text {th }}$ classes (pupils about 13-14 years old), regardless of their specialisation (Kosętka 1985, 65). It was taught in Polish literature classes and compared with Ludwik Kubala's work, as Kijas did in the aforementioned article. But this situation did not last for long, especially since the tenor of the first part of the Trilogy, With Fire and Sword, gradually became considered unsuitable for the education of young citizens by the Ministry of Education in the Sanacja government.

Indeed, the context in which Kijas and Iwaszkiewicz praised the pedagogical virtues of Sienkiewicz's first novel was very different from the time of its creation. The Polish state was founded after the Treaty of Versailles, but -more importantly for the reception of Sienkiewicz's first novel- also after the Polish-Soviet War (1920), which resulted in large territorial gains to the East for Poland. These eastern regions were populated by a high proportion of Ukrainian inhabitants and the recognition of their minority rights became one of the central political problems of the Second Polish Republic (Benecke 1999).

In 1926, Józef Piłsudski carried out a coup and a new regime came to power. The regime's answer to the complex issue of minorities focused on loyalty to the state. This translated into firm integration policies via the army and the school system. In 1928 to 1932, a school reform aimed at unifying the schools inherited from the three partition states was launched by Janusz Jędrzejewicz (1885-1951), Minister of Religious Faiths and Public Education. ${ }^{11}$ Alongside the many crucial aspects of this reform, including making primary school compulsory and unifying the curriculum for all schools, a marginal one was the withdrawal of Sienkiewicz's

11 The school reform law was voted by the parliament on 11.03.1932. Available on: http://prawo.sejm.gov.pl/ isap.nsf/DocDetails.xsp?id=WDU19320380389

CONNEXE 5 | 2019 - Divided Memories, Shared Memories, Poland, Russia, Ukraine: History mirrored in Literature and Cinema 
With Fire and Sword from the compulsory reading list. The argument for this withdrawal was its "anti-state" character (Kosętka 1985, 69). Not only did the novel not serve the purpose of creating adherence and loyalty to the Polish state, but in regions with large Ukrainian populations (and so-called minority schools) it was even counter-productive, as it was destroying the "efforts for assimilation" of these minorities within the Polish state (Kosętka 1985, 78), especially since the book was set in territories that were no longer part of the Second Republic. The reform came into effect in July 1932, and consequently in 1933 -the $50^{\text {th }}$ anniversary of the publication of With Fire and Sword-, the novel was removed from the compulsory reading list in primary schools. The extent to which the withdrawal of With Fire and Sword was implemented is difficult to assess ${ }^{12}$ but it did not affect its lasting popularity among Polish readers as attested by its continual reprinting in the 1930s.

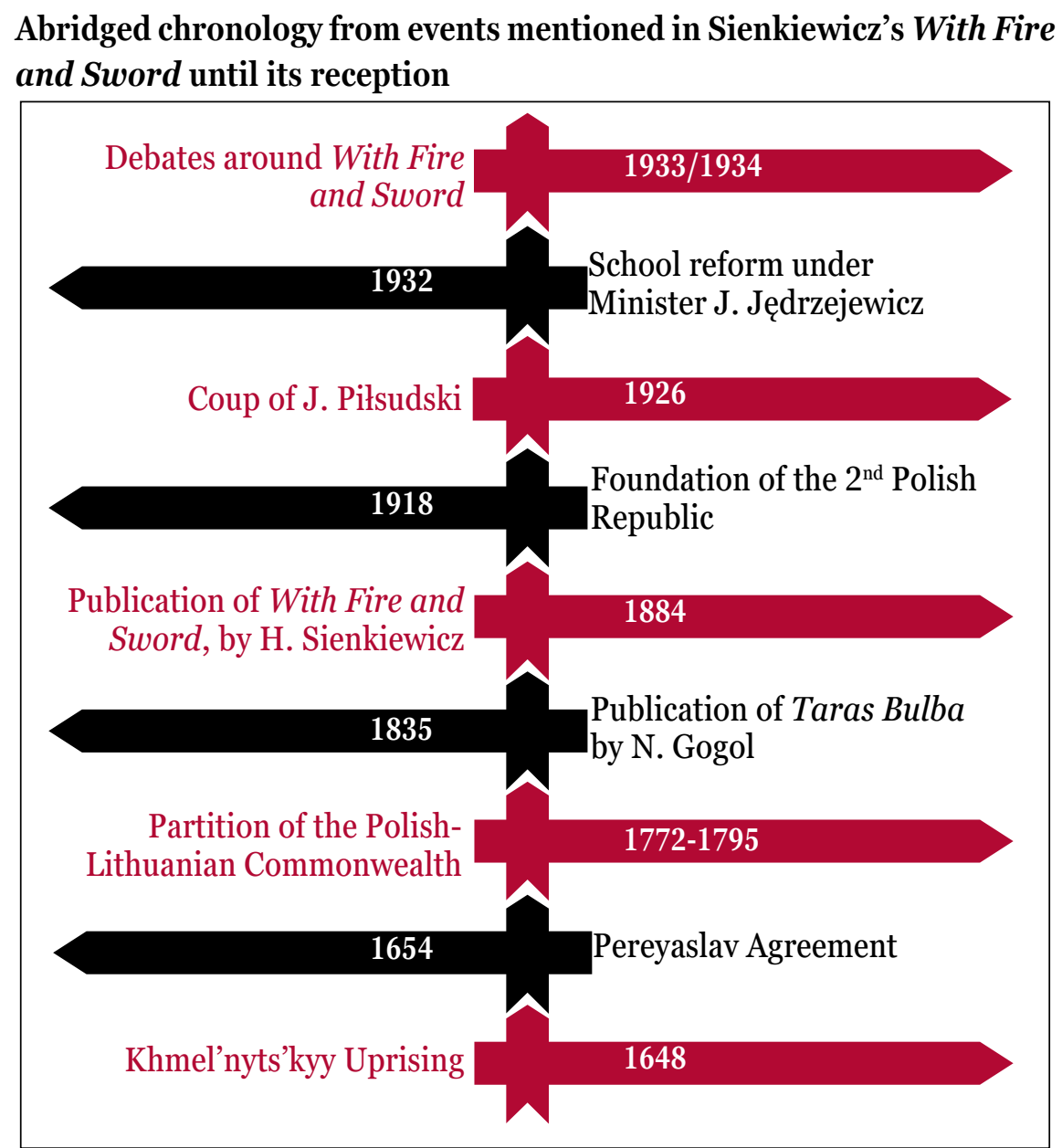

12 The novel was still featured in handbooks after 1932, both for history and literature classes (for instance: Lekcje wzorowe 1935; Korycki 1933). 
2. Reading With Fire and Sword in Polish schools: A battle for the social imagination in 1933-1934 Poland

Given the aura the novel and its author possessed, the reactions to its withdrawal were dominantly critical, especially from the conservative side, reacting to the campaign launched by officials in the Ministry (ABC 1933). But it seems that the debate took a more impassioned turn after one Polish public figure close to the Sanacja government, Olgierd Górka (1887-1955), became involved.

\subsection{Sparking the debate: Olgierd Górka's stances in Pion (1933)}

On 21 October 1933, the newly founded literary magazine Pion ${ }^{13}$ published an article written by Olgierd Górka with the unequivocal title "With Fire and Sword and the historical reality" (Górka 1933b). In this article, Górka formulated a clear criticism of Sienkiewicz's novel, drawing on the importance of historical reality as a basis for harshly condemning how the novel had been used under the new Polish regime. This article sparked strong reactions in the press ${ }^{14}$ and several books, ${ }^{15}$ which Górka answered in turn via a press article and a book (Górka 1934b). In his response in the press, Górka justified his participation in the debate not because of his particular expertise on the matter -he recognised himself that he would have preferred to write his piece later after having conducted his own research-, but because he had been inspired by the context of the school reform and recently published books. ${ }^{16}$ His support for the withdrawal of the text is in line with the government position, but he goes one step further. Sienkiewicz's novel cannot be used in class because it created a false representation of the past. For Gorka, the problem does not lie in the fact that there may be some historic inaccuracies in the plot, which is perfectly legitimate in a novel, but in the fact that the general representation of the historical situation is inaccurate (Górka 1933b, 6). He lists elements that had been criticised by other historians to make the point that while one cannot change a literary creation, the archives do not change either and they cannot be adapted to a new historiographical context. But it is not only the historiography that Gorka uses to create some distance between the novel and the historical facts: his central criticism relies on the impact on the social imagination of Polish society at the time. He refers to the Swiss myth of William

13 This publication was soon identified as a non-official channel of the Sanacja government in cultural matters: see Marciniec 2016.

14 For a detailed account of the press debate, see Kosętka 1985.

15 One outspoken and long-standing opponent was for instance the conservative MP Zygmunt Lasocki (18671948): Lasocki 1935, 1934. A collection of selected texts can be found in Kosętka 2006.

16 Notably Tomkiewicz 1933.

CONNEXE 5 | 2019 - Divided Memories, Shared Memories, Poland, Russia, Ukraine: History mirrored in Literature and Cinema 
Tell, stating that although this character did not exist, the story constructed about him is plausible: he could have existed, and therefore the national narrative created around this character is not misleading.

In the previously mentioned analysis on social imagination by Baczko, the state plays a central role in the production and dissemination of these "landmarks" because the fight for power also takes place in the realm of the social imagination for the prerogative of interpreting these references. Górka positions himself as a protagonist in this battle: to serve his state, he brings his academic legitimacy to strengthen the official argument. In other words, to back up his claim that the social imagination of Poles with regard to Sienkiewicz's novel needed to change, he used academic arguments to fuel the discussion. Górka claimed that Sienkiewicz had fixed the contemporary historiographical situation in the social imagination, not only that of Poles but also that of Polish historians. He regretted that current Polish historiography remained within the general image conveyed by Sienkiewicz - especially, from a methodological point of view, the Polish-centred perspective on this history. Finally, he accused his colleagues of drawing solely on Polish language sources and not comparing them with Ottoman, Russian and other sources, thereby contributing to the distorted vision of these events. He used his experience as a mediaeval historian who worked with sources in various languages. In the book published as a final contribution to this debate, in 1934, his criticism was even more directly targeted at the social imagination linked to the work of his fellow historians. For Górka, one way to escape Sienkiewicz's legacy in Polish society would be to return to more fundamental historical research, exhibiting the brutality of the battles or presenting the characters in the novel from a historically realistic perspective rather than in a heroic way (Górka 1934b, 14-15). He advocated awareness of the sources used in general by historians, which are often chronicles written in their own language, in a particular context, often long after the events described (Górka 1934b, 171). Not only did he attack a monument of Polish culture; in the name of political reform, Górka also displayed a provocative attitude that soon became one of the major reproaches he faced, especially as it was combined with a position of authority. ${ }^{17}$ His campaign for a revision of the historiography had already started in February 1933 (Górka 1933a). ${ }^{18}$ In that article, he made more general claims on the lack of historiographical work dedicated to the south-eastern borderlands of Poland, in contrast with the north-western territories, which were disputed with Germany.

17 He positioned himself as an academically endorsed historian but dealt with issues outside his specialised field. 18 The article was later reprinted as a brochure: Górka 1934a.

CONNEXE 5 | 2019 - Divided Memories, Shared Memories, Poland, Russia, Ukraine: History mirrored in Literature and Cinema 
He presented historiography as a highly politicised science. The historiography of the south-eastern region was primarily addressed from the angle of the decline of the Polish-Lithuanian Commonwealth, ${ }^{19}$ much in the same way as Sienkiewicz did. The resulting image was one of a lost paradise, of a previously strong Polish state (which is echoed in the reactions to Górka's position in the press). Górka called for a revision of the historiography along the lines of the previously mentioned inventory: the use of foreign sources, the introduction of more demographic information and military analysis, and ultimately moving beyond monographs focusing on a particular event and striving for a more general history of the region over time.

Olgierd Górka already had lengthy experience of combining political engagement with an academic career. He started with a thesis in 1911 on the mediaeval history of a city in Silesia, disputed by the Germans and the Poles. During World War I, as he embarked on his military career, he moved closer to Piłsudski and his legions. He also pursued his academic career, obtaining his accreditation to supervise research in 1916 in Lemberg. This dual career meant that Górka was particularly sensitive to the question of the political use of knowledge, especially historical knowledge, for the creation and later, defence of the Polish state (Romek 1997). He recognised the risk for the Polish state in its ongoing conflict with Ukrainian minorities. In a context of political violence and repression, Górka was one of several who tried to bring the Ukrainian viewpoint into the Polish public debate. However, it is worth noting that the anti-Semitic violence that marked the Uprising is barely mentioned, either by Górka or by his later opponents, nor was the role Khmel'nyts'kyy played in other cultures and historiographies.

\subsection{The unheard Ukrainian voices in the Polish public debate}

In this debate, the Ukrainian perspective was picked up sporadically by some voices in the Polish press: for instance, the linguist Zygmunt Leśnodorski (19071953) (Leśnodorski 1933) ${ }^{20}$, or the conservative journalist Adam GrzymałaSiedlecki (1876-1967) (Grzymała Siedlecki 1933), who even compares his own experience when reading Taras Bulba by Nikolay Gogol to Ukrainian pupils being forced to read Sienkiewicz. He recalls that he first disliked Gogol's novel, perceiving it as an attack by the Russian empire against Poles. But later on, he enjoyed Gogol's masterpiece outside the constraints of the classroom. Doing so, he compares the Ukrainian situation to the Polish one under the pre-1918 Tsarist

19 Here named only from the Polish point of view as the First Polish Republic.

20 Note that this was the newspaper that published Sienkiewicz's novel in the first place.

CONNEXE 5 | 2019 - Divided Memories, Shared Memories, Poland, Russia, Ukraine: History mirrored in Literature and Cinema 
domination and concedes that Sienkiewicz's text could be perceived negatively because of its Polish patriotic aura. Another prominent conservative forum where supporters of Górka's conception of the state and the assimilationist view of policies towards minorities could be found was the journal Nasza Przysztość [Our Future] (Pogonowski 1934). Although from opposing sides, these voices were in line with the need for the Polish state to obtain the loyalty of the Ukrainian minority in order to stabilise the presence of Poland in the eastern territories.

The Polish state itself, using state structures such as the school and the army (Benecke 1999), also indirectly supported initiatives to foster dialogue within Ukrainian political forces, that were potential allies of the state. One example was the Polish-Ukrainian Bulletin [Biuletyn Polsko-Ukraiński] (Libera 2011), founded in 1932. The Polish-Ukrainian Bulletin gave itself the mission of organising dialogue between Ukrainians and Poles within Poland. It was created following the assassination of Tadeusz Hołówko (1889-1931), a strong advocate for PolishUkrainian alliance, on 29 August 1931. Moreover, the Polish-Ukrainian Bulletin was created in the aftermath of the "pacification" of Eastern Galicia in autumn 1930, when the police carried out mass arrests of activists of the Ukrainian cause, following sabotage by the Organisation of Ukrainian Nationalists (OUN). From 1932 to 1938, it published contributions in Polish (with translations of Ukrainian contributions) on political issues, with information about Soviet Ukraine, including the Holodomor. The Polish-Ukrainian Bulletin was supported by the Institute of the East (Instytut Wschodni, IW), whose secretary general was Olgierd Górka. The aim of this institute was to raise awareness about Eastern questions and educate young people, especially the rising political elite, about Pilsudskian conceptions of Eastern politics. As early as 1927, two state bodies supported the IW: the Ministry of Foreign Affairs and the $2^{\text {nd }}$ Department of the Polish General Staff (Oddziat II Sztabu Generalnego Wojska Polskiego), in charge of intelligence. To that extent, the IW and the Bulletin were virtually state operations, led by figures sensitive to Polish state policy who wanted to offer their knowledge and make it useful to Polish politics, while remaining outside state structures, therefore without official accountability. When the debate around Sienkiewicz's novel arose, the PolishUkrainian Bulletin defended the withdrawal of the novel from the compulsory reading list, in the name of mutual respect towards the pupils of "Ukrainian high schools" (Krzowski 1933). But the vast majority of reactions in the press and in essays published to mark the education reform did not recognise the grounds proposed by the reformers, to remove a text that could stir up Polish-Ukrainian conflict, and maintained a Polish-centric view on the issue. 
In response to Adam Grzymała-Siedlecki and a few months before Górka's first publication on Sienkiewicz, on the front page of Kurjer Warszawski, another unnamed journalist proposed reversing the argument put forward by the state (Kurjer Warszawski 1933). He claimed that it was impossible to compare Taras Bulba and With Fire and Sword, since the latter was much more balanced towards both Poles and Ukrainians. He noted that Bohun was often the favourite character and that Sienkiewicz's novel contained many Ukrainian characters that were loyal to the Polish Crown. To that extent, in his eyes, the novel was actually a useful resource for familiarising Ukrainians with the Polish point of view of these historical events, without upsetting them; it was therefore an essential tool for their assimilation. This article returned to the original view of Sienkiewicz's novel as a resource for both historical and patriotic education and tried to reconcile Polish and Ukrainian patriotism. This is one example of the defence of a Polish-centred imagination as read in Sienkiewicz's novel. Indeed, very few articles of the Polish press even mention the Ukrainian point of view, let alone quote any Ukrainian intellectuals or politicians. As commented in one article reporting on a public discussion between Górka and one of his opponents, Władysław Tomkiewicz, the "Ruthenian question" quickly disappeared from the debate (ABC 1934b) to focus on the question of the persistent relevance of Sienkiewicz for shaping Polish pupils into patriots. The reactions to the novel's withdrawal were rather defensive and even at times frankly hostile to the "professional advocates of the national minorities" (Charkiewicz 1933) and their idea of reducing Sienkiewicz's presence in the schools to appease Polish-Ukrainian tensions. The opposition to assimilationist policies treated Sienkiewicz instead as a hallmark of Polish culture that had to be defended.

\subsection{Rescuing Sienkiewicz: Opposition to the state-centred definition of Polish culture}

Górka's intervention in the debate in October 1933 repositioned the discussion of patriotic education on the historiographical plane: from then on, the question was whether the novel depicted "historical reality" and if this depiction, "enhanced" by the literary talent of its author, would be a suitable source for the patriotic education of all Polish citizens.

Among literary scholars, many voices tried to reclaim the right to pass judgment on Sienkiewicz from historians. For instance, the Slavist Józef Birkenmajer (Birkenmajer 1935) attacked Górka, claiming that he was ill equipped to discuss literary work -Górka judged Sienkiewicz as a failed "PhD 
candidate in history," ${ }^{21}$ but Birkenmajer saw this as irrelevant. Sienkiewicz's work should be judged "according to the rules of poetry" and certainly not according to the historiographical standards of the 1930s or sources that were unknown to Sienkiewicz at the time he wrote the novel (Birkenmajer 1935, 620-621). After saying that, Birkenmajer referred to Zygmunt Lasocki’s criticism of Górka, however, challenging the Górka's claim that the ethnic/religious group of the main protagonist of the novel, Jan Skrzetuski, was not Catholic but "Ruthenian." Birkenmajer alternated constantly between historical arguments on the one hand, and arguments based on the nature of the novel and its right to take liberties with historical reality on the other. He argued that Sienkiewicz was able to form his own representation of the past, independently from Kubala, thanks to his own research, thereby giving him historical legitimacy. Finally, Birkenmajer referred to the content of the novel, contesting the negative image of the second main protagonist, Bohun, since in fact Bohun was often the preferred character of the novel. For Birkenmajer, the popularity of Bohun casts doubt over the negative representation of the character and, by extension, the Cossacks, as claimed by Górka. The intertwining of history and fiction in the novel and above all its patriotic aura made its defence a rather complex task. Birkenmajer used arguments from all fields to defend With Fire and Sword, cementing its ambiguous function in Polish culture.

One of the most noticed defenders of Sienkiewicz was the historian Stanisław Zakrzewski (1873-1936) (ABC 1934a), Górka's PhD supervisor, who supported Górka's appointment as professor. ${ }^{22}$ It was Zakrzewski's talks in February 1934 (Pohorecki 1934; Romer 1934) that generated the most press coverage. Feliks Hubert Pohorecki (1890-1945) was one of the few to report on the beginning of Zakrzewski's talk, where he explained the historical context of the conflict. Zakrzewski depicted the history of Ukraine as being the history of a space in between several political entities - Muscovy, the Ottoman Empire and Polandand described how the Poles colonised the region, "spreading culture" and "normalising" the situation (much as the "civilising" work of the Wiśniowiecki family is depicted by Sienkiewicz). This normalisation meant that the territory was gradually brought under the plough, and the inhabitants, the Cossacks, were employed as peasants by the Polish aristocracy. They were also called up

21 In reference to Górka's first article published in Pion, where he used that expression.

22 The appointment committee selected Górka on 4 October 1933 after having heard from Stanisław Zakrzewski and literature historian Juliusz Kleiner (1886-1957). The Minister of Education approved his appointment in April 1934. See Górka's personal file at the Ministry of Religious Faiths and Public Education of the Second Polish Republic: AAN, Ministerstwo Wyznań Religijnych i Oświecenia Publicznego, Akta osobowe, 2692. 
as soldiers to defend the land, but they did not receive sufficient recognition in terms of social status. As reported by Pohorecki, Zakrzewski claimed in his presentation that this was the seed of the Cossack Uprising. This element, namely the underlying conflict over the historical legitimacy of possession of the then disputed territories, is rarely mentioned in the broad discussion about the novel. It is not to say that Sienkiewicz's defenders were claiming the 17th-century territory "back," but it does echo the conflict over legitimacy that arose between the Poles and the Ukrainians in the interwar period and took a violent turn in the early 1930s. Zakrzewski did not seem to dwell on these historical issues. He went on to directly address Górka's criticism of Sienkiewicz and to refute the former's arguments one after the other. As a historian, Zakrzewski reiterated that Górka's criticism was nothing new: Górka merely repeated the historiographical debate between Szajnocha and Kubala but without mentioning his sources. What is more, Zakrzewski did not see the novel as being a source of conflict, as claimed by Górka.

A few weeks after Zakrzewski's talks, another article reported on his views, along the same lines but insisting on the manipulative transposition of historical debates into the public sphere and their instrumentalisation for political debate (Kukiel 1934). Marian Kukiel (1885-1973) explained how, when he discovered as a young man that Sienkiewicz sided with Kubala against Szajnocha, he became aware of the relative nature of the historical narrative. He recalled that he was initially distressed by the fact that Sienkiewicz was facing the same difficulties as any historian trying to capture a particular historical situation. With hindsight, however, he came to admire Sienkiewicz even more, especially his talent for building on meagre historical sources and discordant voices from the past to create such a vivid character as Jeremi Wisniowiecki. The conclusion he drew from his experience was to ridicule Górka's "revelations;" he called on him to abandon his publicist activities to return to his historical research, which he acknowledged as fruitful. Władysław Konopczyński (1880-1952) came to a similar conclusion (Konopczyński 1934). These examples show how historians put a great deal of effort into discrediting Górka as a historian, seemingly for sharing his doubts about historiographical practices with laymen in the public space. All these historians confirmed the role of Sienkiewicz as an educator of the Polish nation and his novel as a tool for the assimilation of the Ukrainian minority. In other words, the historians who "rescued" Sienkiewicz began their arguments by reiterating historiographical debates but ended up defending the image of the history they conveyed for the sake of "patriotic" education. 
Among the historians, it seems that Oskar Halecki (1891-1973) was one of the few to catch the epistemological ball thrown by Górka (Halecki 1934). Halecki did not adopt Górka's tone and did not attempt to contribute to discussions on the historical facts, as he was not a specialist of the period. However, he acknowledged the "merit" of Górka's call for a diversification of historical sources to deal with the past. This should not amount to a complete "revision" of Polish historiography, however; Halecki concluded that beyond the changing Zeitgeist or the subjectivity of a national point of view, one element of Polish historiography that should remain stable was "Christian ethics" (Halecki 1934, 314). Halecki spends most of his article describing the various attempts by Górka to call for a revision of Polish historiography - at the Polish Historians' Conference in 1925 in Poznań and in his previously mentioned book (Górka 1933a, 1934a) - which were not echoed in any significant way within the profession.

On the contrary, it appears that the combination of Sienkiewicz's aura, the media chosen to convey the criticism and the context of a reform that had major symbolical implications for how the Polish state and national culture were conceived, was more effective in drawing attention to the Polish-Ukrainian question, but not in building a new consensus on the social representation of the Polish-Ukrainian past and its implications for the present. The sensationalism of the press and the hybrid nature of Sienkiewicz's novel, not to mention Górka's taste for controversy, significantly disrupted the discussion. Ukrainian voices, whether from Ukrainian historiography or Ukrainian publicists and intellectuals, remained largely unmentioned by the Polish debaters.

Górka did not change his position significantly during the debate, as shown by his answers, which he also compiled in a short book dedicated to the controversy (Górka 1934b). He repeated his claims, with a few more factual details, and described at length some of the battles discussed by Ludwik Kubala to highlight the gaps in knowledge on them and the importance of the narrative built by Kubala. This became the leitmotiv of his response to the debate: the lack of knowledge had become invisible because of the effective narratives that were built concerning the period. In this article, he focused less on Sienkiewicz than on historians.

In the 1934, June issue of Pion, however, one of Górka's answers was published alongside an article by Tadeusz Skrzetuski tackling the nationality of the namesake hero of With Fire and Sword, Jan Skrzetuski (Skrzetuski 1934). Tadeusz referred to archives describing Jan as "Ruthenian" but also noted that the historical figure of Jan Skrzetuski actually fought against Khmel'nyts'kyy, a fact which is ultimately more relevant than his nationality. This is one example 
of a more nuanced contribution to the discussion that seems to have remained marginal in the press as well as in the fiery historiographical debate ignited by Górka, which mainly consisted in either using historical sources to discredit Górka (exactly those which Górka criticises as being one-sided) or (and often at the same time) claiming the right for Sienkiewicz to take some liberties with historical reality when writing a fictional work. All of these challengers to Górka defended Sienkiewicz's place in the Polish social imagination.

The discussion revolved around the question of Polish patriotism and national culture and Sienkiewicz's role in it. The debate seems to have reached its culmination in early 1934 with the lectures by Zakrzewski, the ensuing articles in February 1934 and the final series of articles published by Pion in June 1934. In the second half of the year, the controversy seems to have gradually petered out, as seen in the letter sent by Władysław Tomkiewicz to Pion in 1934 stating the impossibility of discussing the matter further via the press.

\section{Prospects: Disentangling Sienkiewicz's heritage}

Sienkiewicz left a legacy in the historical imagination of both Poles and other peoples that has lasted until the present day. The overlap between his narrative and the historiography is inescapable: reference books dealing with the Uprising repeatedly mention With Fire and Sword. Just like in other countries and with other issues, the 19th-century historical image still has a strong impact today in shaping our representation of (national) history, especially the one shaped by the literary works of the time (Lyon Caen 2019; Surynt 2012). What has changed, however, is the role attributed to Sienkiewicz's novel: it seems that the novel is no longer mentioned in historical accounts as a starting point for understanding the 17th century, but rather the 19th century; it functions instead as a coping strategy for Polish society with its current borders (Beauvois 2010,142) and as a product of the literary and political tradition of its time (Bujnicki and Axer 2007). This change of perspective occurred after several social debates but primarily following the radical changes in situation after 1945 and 1989.

The 1933-1934 controversy around Sienkiewicz's novel With Fire and Sword gives us an insight into the Polish social imagination in the critical period of the Second Polish Republic and the conflict between conservative intellectuals and state-centred intellectuals. Notwithstanding the controversial stance adopted by Górka, the reactions to his claims show that for large portions of Polish intellectuals and scholars it was not acceptable to relativise Sienkiewicz's position in the Polish political culture, even if political tensions over the position of the Ukrainian 
minority were tangible. This by no means legitimises the withdrawal of With Fire and Sword from the compulsory school reading list, but the fact that the other two parts of the trilogy were not even considered for withdrawal is noteworthy. This discussion found an echo in 1985-1986 with the works of the literature historian Halina Kosętka on this debate (explicitly siding with the defenders of Sienkiewicz (Kosętka 1985). A few months later, the Polish Ministry of Defence republished the book that Górka had written in response to his opponents fifty years earlier (Górka 1986) and a hundred years after the first publication of the novel itself. Halina Kosętka republished in the same issue in 2006, an edition of the articles criticising Górka (Kosętka 2006). That same year, historians engaged in discussions over several weeks and in various locations concerning the legacy of Sienkiewicz in contemporary societies in Lithuania, Poland, Ukraine and beyond. Their discussions were transcribed under the broad title Why Sienkiewicz? [Po co Sienkiewicz?]. The discussions of With Fire and Sword again touched upon the historicity of the novel, with a brief reference to the controversy of 19331934. This time, however, the conclusion of the discussions, proposed by cultural historian Andrzej Mencwel, was a call to study the myth created by Sienkiewicz's work rather than the historical roots of the novel (Bujnicki and Axer 2007, 272).

\section{Bibliographical references}

\section{Primary sources of the debate ${ }^{23}$}

Birkenmajer, Józef. 1935. “Prace o Sienkiewiczu.” Pamiętnik Literacki: Czasopismo Kwartalne Poświęcone Historii i Krytyce Literatury Polskiej 32 (1): 609-626.

Charkiewicz, Walerjan. 12 November 1933. "Spryciarz - Ten Pan Sienkiewicz!..” Kurjer Nowogródzki - W Niszy.

Górka, Olgierd. 1933a. "Dziejowa Rzeczywistość a Racja Stanu Polski Na PołudniowymWschodzie." Polityka Narodów 1/2: 6-33.

Górka, Olgierd. 21 October 1933b. “'Ogniem i Mieczem' a rzeczywistość historyczna.” Pion: tygodnik literacko-spoteczny.

Górka, Olgierd. 1934a. Dziejowa Rzeczywistość a Racja Stanu Polski Na PotudniowymWschodzie. Warsaw: Libraria Nova.

Górka, Olgierd. 1934b. 'Ogniem i Mieczem’ a Rzeczywistość Historyczna. Warsaw: Libraria Nova.

Górka, Olgierd. 1986. 'Ogniem i Mieczem’ a Rzeczywistość Historyczna. Warsaw: Wydaw. Min. Obrony Narodowej.

Grzymała Siedlecki, Adam. 24 June 1933. “Pod światło. ‘Ogniem i Mieczem’ w szkołach dla Rusinów." Kurjer Warszawski.

23 From the digitised collection available on polona.pl and listed here:

https://www.zotero.org/groups/2373010/sienkiewicz - with fire and sword - interwar poland

CONNEXE 5 | 2019 - Divided Memories, Shared Memories, Poland, Russia, Ukraine: History mirrored in Literature and Cinema 
Halecki, Oskar. 1934. “Czy jest potrzebna jest 'rewizja' dziejów Polski?” Przegląd Powszechny: 295-314.

Kijas, Juliusz. 1927. "Źródła Historyczne Powieści.” Pamiętnik Literacki: Czasopismo Kwartalne Poświęcone Historii i Krytyce Literatury Polskiej 24 (1):119-135.

Konopczyński, Władysław. 22 February 1934. “Fotomontaż historyczny.” Kurjer Warszawski.

Korycki, Władysław. 1933. Podręcznik pomocniczy i syntetyczny literatury polskiej na kl. 4-ta: lektura: Ogniem i Mieczem, Grażyna, Iljada. Warszawa: Dom Książki Polskiej.

Krzowski, Paweł. 1933. “'Ogniem i mieczem’ czy ‘Potop’ w gimnazjach ukraińskich.” Biuletyn Polsko-Ukraiński: tygodnik ilustrowany 2 (25): 5-6.

Kukiel, Marian. 14 February 1934. “'Ogniem i Mieczem’ a odwracana rzeczywistość dziejowa.” Kurjer Warszawski.

Leśnodorski, Zygmunt. 15 October 1933. "Spór o Sienkiewicza." Czas.

Pogonowski, Jerzy. September 1934. "Prawda Tła Dziejowego 'Ogniem i Mieczem.” Nasza Przysztość: Wolna Trybuna Zachowawczej Myśli Państwowej.

Pohorecki, Feliks Hubert. 6 February 1934. “'Rewizja' do gruntu zrewidowana ('Ogniem i Mieczem' w świetle prawdy naukowej)." Kurjer Poznański.

Romer, Helena. 20 February 1934. “Turniej historyków.” Kurjer Wileński.

Skrzetuski, Tadeusz. 3 February 1934. "Skrzetuski z ‘Ogniem i Mieczem’ jest prawdziwy!” Pion: tygodnik literacko-spoleczny.

Tomkiewicz, Władysław. 1933. Jeremi Wiśniowiecki: (1612-1651). Warsaw: Nakładem Towarzystwa Naukowego Warszawskiego .

"Ogniem i mieczem a Rusini." 31 July 1933. Kurjer Warszawski.

"Pod hasłem 'wychowania państwowego' Walka z 'Ogniem in Mieczem' nie ustaje nawet na terenach rdzennie polskich.” 6 August 1933. $A B C$.

"W obronie ‘Ogniem i Mieczem' wystąpili uczeni lwowscy.” 6 February 1934a. ABC.

"Książe Jeremi Na plus i Minus. Dyskusja Historyczna o 'Ogniem i Mieczem.”' 11 February 1934b. $A B C$.

Lekcje wzorowe na każdy dzień i każdą godzinę lekcyjna szkoty powszechnej: oddziat (klasa) VI. Z. 30, 1-6 kwietnia. 1935. Warszawa: Wydaw. Drapczyńskich.

\section{Bibliography}

Baczko, Bronislaw. 1984. Les imaginaires sociaux: mémoires et espoirs collectifs. Paris: Payot. Beauvois, Daniel. 2010. La Pologne des origines à nos jours. Paris: Le Seuil.

Benecke, Werner. 1999. Die Ostgebiete der Zweiten Polnischen Republik: Staatsmacht und öffentliche Ordnung in einer Minderheitenregion 1918-1939. Köln: Bohlau.

Bujnicki, Tadeusz. 2007a. "Romantyczny obraz Ukrainy a historyczna wizja w Ogniem i mieczem.” In Po co Sienkiewicz?: Sienkiewicz a tożsamość narodowa: z kim i przeciw komu? Warszawa-Kiejdany-Luck-Zbaraż-Beresteczko, edited by Tadeusz Bujnicki and Jerzy Axer, 252-270. Warsaw: OBTPE.

Bujnicki, Tadeusz. 2007b. “Taras Bulba a Ogniem i mieczem - lektura porównacza.” In Po co 
Sienkiewicz?: Sienkiewicz a tożsamość narodowa: z kim i przeciw komu? : WarszawaKiejdany-Luck-Zbaraż-Beresteczko, edited by Tadeusz Bujnicki and Jerzy Axer, 321-322. Warsaw: OBTPE.

Bujnicki, Tadeusz. 2016. "Powieść Historyczna Według Sienkiewicza. Teoria i Praktyka." Czytanie Literatury. Łódzkie Studia Literaturoznawcze 5: 123-137.

Bujnicki, Tadeusz, and Jerzy Axer. 2007. Po co Sienkiewicz?: Sienkiewicz a tożsamość narodowa: $z$ kim i przeciw komu?: Warszawa-Kiejdany-Luck-Zbaraż-Beresteczko. Warsaw: OBTPE.

Chemodanova, Olena. 2014. “Z dziejów ukraińskiej recepcji ‘Ogniem i mieczem’ Henryka Sienkiewicza.” Wiek XIX, XLIX (VII): 249-259.

Dumasy-Queffélec, Lise. 2011. "Le feuilleton." In La civilisation du journal: Histoire culturelle et littéraire de la presse française au XIXe siècle, edited by Dominique Kalifa, Philippe Régnier, and Marie-Eve Thérenty, 925-936. Paris: Nouveau Monde Éditions.

Gautier, Brigitte. 2009. “'Absalomie, Absalomie’ - Kozacy w 'Ogniem i mieczem’ Henryka Sienkiewicza." Pamiętnik Literacki 2: 31-39.

Glaser, Amelia. 2015. Stories of Khmelnytsky: Competing Literary Legacies of the 1648 Ukrainian Cossack Uprising. Stanford Studies on Central and Eastern Europe. Stanford, California: Stanford University Press.

Henryk Markiewicz, Zenon Jagoda. 1967. “Juliusz Kijas (23 Kwietnia 1899 - 7 Lutego 1967) [Nekrolog].” Pamiętnik Literacki: Czasopismo Kwartalne Poświęcone Historii i Krytyce Literatury Polskiej 58 (3): 301-307.

Iwaszkiewicz, Jarosław. 2016. “Nasz Sienkieiwcz.” Wiek XIX, LI (1): 599-603.

Kalifa, Dominique, Philippe Régnier, Marie-Eve Thérenty, and Alain Vaillant. 2011. La civilisation du journal: Histoire culturelle et littéraire de la presse française au XIXe siècle. Paris: Nouveau Monde Éditions.

Kosętka, Halina. 1985. Z dziejów recepcji 'Trylogï’ Henryka Sienkiewicza $w$ dwudziestoleciu międzywojennym: wokót polemik z Olgierdem Górka. Prace Monograficzne Wyższej Szkoły Pedagogicznej w Krakowie. Krakow: WSP.

Kosętka, Halina. 2006. W obronie 'Ogniem i mieczem': polemiki z Olgierdem Górką: wybór tekstów. Kraków: Wydawn. Naukowe Akademii Pedagogicznej.

Kosman, Marceli. 1999. 'Ogniem i mieczem': prawda i legenda. Poznań: Oficyna Wydawnicza 'G\&P.'

Koznarsky, Taras. 2015. "Heroes and Villains in the Historical Imagination. The Elusive Khmletnytsky." Stories of Khmelnytsky: Competing Literary Legacies of the 1648 Ukrainian Cossack Uprising, edited by Amelia M. Glaser, 89-109. Stanford University Press.

Libera, Pawel. 2011. "Biuletyn Polsko-Ukraiński(1932-1938) - Pismo Ruchu Prometejskiego." Київські Полоністичні Студї̈ 18: 33-41.

Lyon-Caen, Judith. 2019. La griffe du temps: Ce que l'histoire peut dire de la littérature. Paris: Gallimard.

Marciniec, Dariusz. 2016. "Charakterystyka problemów kultury w latach trzydziestych na podstawie publicystyki 'Pionu' (1933-1939).” Acta Universitatis Lodziensis. Folia Historica 96: 191-212.

CONNEXE 5 | 2019 - Divided Memories, Shared Memories, Poland, Russia, Ukraine: History mirrored in Literature and Cinema 
Radzikowska, Dorota. 2015. Pomiędzy reformami: edukacja poczatkowa w polskich reformach oświatowych w latach 1932-1961. Łódź: Wydawnictwo Uniwersytetu Łódzkiego.

Romek, Zbigniew. 1997. Olgierd Górka: Historyk w Stużbie Myśli Propaństwowej (19081955). Warsaw: Semper.

Surynt, Izabela. 2012. "Gustav Freytag \& Henryk Sienkiewicz. (Nie)Moc Literackiego Kanonu”. In Polsko-Niemieckie Miejsca Pamięci, edited by Robert Traba and Hans Henning Hahn 3: paralele, 299-322. Warsaw: Scholar.

Sysyn, Frank. 1998a. "Grappling with the Hero: Hrushevs'kyi Confronts Khmel'nyts'kyi." Harvard Ukrainian Studies 22: 589-609.

Sysyn, Frank. 1998b. "The Changing Image of the Hetman: On the 350th Anniversary of the Khmel'nyts'kyi Uprising.” Jahrbücher Für Geschichte Osteuropas 46 (4): 531-545.

Sysyn, Frank. 2015. "A Man Worthy of the Name Hetman.' The Fashioning of Khmelnytsky as a Hero in the Hrabianka Chronicle." In Stories of Khmelnytsky: Competing Literary Legacies of the 1648 Ukrainian Cossack Uprising, edited by Amelia M. Glaser, 36-46. Stanford University Press.

Teller, Adam. 2015. "A Portrait in Ambivalence. The Case of Natan Hanover and His Chronicle, 'Yeven Metsulah."' In Stories of Khmelnytsky: Competing Literary Legacies of the 1648 Ukrainian Cossack Uprising, edited by Amelia M. Glaser, 23-35. Stanford University Press.

Thiesse, Anne-Marie. 2001. La création des identités nationales. Europe XVIIIe-XIXe siècle. Paris: Points.

Teller, Adam. "Hannover, Natan Note.” In YIVO Encyclopedia, Accessed 29 January 2019. http://www.yivoencyclopedia.org/article.aspx/Hannover Natan Note. 